\title{
The Future of Euro-Mediterranean Migration and Partnership. A Perspective from the Southern Mediterranean
}

\author{
Güney Akdeniz Perspektifinden Avro-Akdeniz Göç Olgusunun ve \\ İşbirliği'nin Geleceği
}

\section{Bachir HAMDOUCH ${ }^{*}$}

\begin{abstract}
In order to explore the future of Euro-Mediterranean migration and partnership, it is necessary to make an incursion into the past and the present. Two observations will serve as a point of departure: the importance of migration in Euro-Mediterranean relations; the failure of the Euro-Mediterranean Partnership (EMP) and the handling of the migration issue.

Migration is an important component of relations between Europe and the South of the Mediterranean. More than ten million immigrants from the Southern and Eastern Mediterranean live in Europe. They transfer about 15 to 20 billion Euros annually to their countries of origin, far more than foreign direct investment and public development $\mathrm{aid}^{2}$. And yet the EMP, itself in breakdown, neglects or even ignores this fact. The EMP has been out of action for a long time. Migrations around and across the Mediterranean are currently in crisis.

The purpose of this Communication is to consider their future, on the basis of the dual failure of the EMP and the treatment of the migration issue. Thus, we will deal with the question in three parts: the first will focus on the failure of the EMP, the second will deal with the limits of handling the migration issue and migration policies, and the third will focus on the prospects for Euro-Mediterranean migration and partnership.
\end{abstract}

Keywords: Migration, Southern Mediterranean, Euro-Mediterranean Partnership, Immigrants

\section{Öz}

Avro-Akdeniz göçünün ve ortaklığının geleceğini anlamak için geçmişe ve bugüne bakmak gerekir. Avro-Akdeniz ilişkilerinde göç olgusunun önemi, Avro-Akdeniz Ortaklığının başarısızlığı ve göç meselesinin ele alınış biçimleri bu yazıdaki önemli çıkış noktalarımız olacaktır.

Göç Avrupa ile Akdeniz’in güneyindeki ülkeler arasındaki ilişkinin önemli bir unsurudur. Avrupa’da, Güney ve Doğu Akdeniz'den gelip yaşayan kişilerin sayısı 10 milyondan fazladır. Bu insanlar her

INSEA, Mohamed V University - Rabat and AMI, bachirhamdouch@gmail.com

** According to our estimates. Morocco alone has about four million immigrants in Europe, Turkey as many and some two million from Algeria and Tunisia. Morocco receives $€$ 6-7 billion per year of transfers from Moroccans living abroad, more than three-quarters of them from Europe. See also OECD, the annual report on Trends in International Migration. 
yıl anavatanlarına 15-20 milyar Avro transfer etmektedir. Bu miktar Akdeniz’in güneyindeki ve doğusundaki ülkelere yapılan kalkınma yardımlarının miktarından çok daha fazladır. Bununla birlikte çökmekte olan Avro-Akdeniz Ortaklığı projesi bu olgunun önemini ihmal etmektedir. AvroAkdeniz Ortaklığı sürecinde uzun zamandır herhangi bir gelişme gözlenmemektedir. Akdeniz’deki ve etrafındaki göç olgusu bir krizin içindedir.

Bu makalenin amacı Avro-Akdeniz Ortaklığının ve göç olgusunun ele alınış biçiminin başarısızlıklarını temel alarak gelecekleri üzerine düşünmektir. Bu çerçevede konuyu üç bölümde ele alacağız: Birinci kısım Avro Akdeniz Ortaklığının başarısızlığına odaklanacaktır. İkinci kısım ise göç olgusunun ve göç politikalarının ele alınışına dair sınırlılıklarla ilgilenecektir. Üçüncü kısım ise Avro-Akdeniz göçüne ve ortaklığına dair gelecekteki beklentilere odaklanacaktır.

Anahtar Kelimeler: Göç, Güney Akdeniz, Avro-Akdeniz İşbirliği, Göçmenler

\section{Introduction: The Failure of the Euro-Mediterranean Partnership}

In our view, the failure of the EMP stems mainly from a misconceived and narrow conception of partnership and a bilateral mode of operation ${ }^{1}$.

\section{Misconception}

The EMP is mainly based on free trade agreements, which are destructive of economic activity in the Southern Mediterranean. They are destructive because they are built on the reciprocity of the advantages granted on both sides. But free trade between countries with unequal levels of development and subsidies granted to producers in European countries creates conditions of unequal competition that destroy production in the Southern Mediterranean, particularly in the agricultural sector, which contributes to rural exodus and international emigration.

The modus operandi consists of bilateral negotiations between the European Union (EU) ${ }^{2}$ and each of the Southern and Eastern Mediterranean countries which result in bilateral agreements.

Three successive agreements have been signed: "Association Agreements" of the 1960s, "Cooperation Agreements" of the 1970s and 1980s and "Euro-Mediterranean Association Agreements" of the years 1990-2000, following the Conference of Barcelona ${ }^{3}$. Although they cover more and more areas of cooperation, the Agreements have four components: political, economic, financial and socio-cultural. However, they still proceed from the same approach, with the same spirit, the main thing being the establishment of a Euro-Mediterranean free trade area,

1 Another reason is certainly the lack of economic integration in the Southern Mediterranean which, moreover, was not encouraged by the EU's modus operandi that negotiated with each of the separate South-Mediterranean countries.

2 We will speak for convenience of the European Union, knowing well that it has borne other names before, Common Market, and European Economic Community.

3 Hamdouch B. (April 2002). 
migration being either ignored or treated in a negative way. The procedure has always remained the same: bilateral negotiations between Europe and each of the South and East Mediterranean countries. Even after the Barcelona Conference (1994), which was multilateral!

\section{Bilateral Agreements}

There were agreements before and after the 1994 Barcelona Conference. Two types of agreements were concluded before the Barcelona Conference, the Association Agreements and the Cooperation Agreements. The "Association Agreements" of the late 1960s (1969 for the three countries of the Maghreb, Morocco, Algeria, Tunisia) are fixed-term trade agreements, generally five years, which provide for reciprocal preferences between the EU and the Mediterranean country concerned. The "Cooperation Agreements", signed in 1976 between each of the three countries of the Maghreb and the EU, are of indefinite duration and are not only trade agreements. They also deal with technical cooperation and financial cooperation.

The Barcelona Conference has a great ambition, which, according to its Final Declaration, is to build a Euro-Mediterranean area of peace and prosperity, in a spirit of reciprocity, based on a broader partnership including three other aspects: political, financial and socio-cultural. Regular dialogue is planned for each of the three components. The economic component consists mainly of the establishment of a vertical free trade area, i.e. between the EU and each of the partners by 2010, free trade between the partners not being covered by these agreements. Genuine free trade in the Euro-Mediterranean area - that is to say vertical and horizontal - would have required multilateral negotiations bringing together all stakeholders around the Mediterranean - such as the Barcelona Conference - and a global free trade agreement, leaving peculiarities to be addressed in complementary agreements.

The Euro-Mediterranean Association Agreements that followed the Barcelona Conference ${ }^{4}$ were passed with all the South and East Mediterranean countries. They are based on the Barcelona Declaration and include the four components: political, economic, financial and socio-cultural. The resulting free trade agreements provide for a tariff dismantling of both partners (EU and Southern partner countries) in a spirit of reciprocity, without taking into account differences in their levels of development.

\section{Migration as a "Parent pauvre"Poor Parent" of the Euro-Mediterranean Partnership and the Limits of Migration Policies}

These are in fact the limits of the treatment of the migration issue by the Euro-Mediterranean agreements and the migratory policies themselves. Migration is the issue the EMP left behind both before and after the Barcelona Conference.

4 However, the agreements with Tunisia and Morocco were signed before the Barcelona Conference, but they proceed in the same spirit. Cf. Hamdouch B. (April 2002) 


\section{Migration, “Parent pauvre"Poor Parent” of the EMP}

Migration is the "parent pauvre"poor parent of the Euro-Mediterranean agreements. It is absent from the Association Agreements of the 1960s and the Cooperation Agreements of the 1970s. The latter nonetheless refer to the non-discriminatory treatment of immigrant workers. Migration, on the other hand, was the subject of bilateral labour agreements between the main European immigration countries at the time (France, Germany, Holland, Belgium) and each of the Maghreb countries since the 1960s. It should be noted in this connection that the application of the non-discriminatory treatment of migrant workers is unsatisfactory, as the judgments of the European Court of Justice show ${ }^{5}$.

The Barcelona Declaration deals with migration in the section on "Partnership in the social, cultural and human spheres" and not in the economic part, although it is first and foremost a labour force $^{6}$. It reiterates the protection of the rights of regular immigrant workers, but nevertheless contains a contradiction. On the one hand, it "recognizes the importance of the issue of migration in Euro-Mediterranean relations", and on the other it wants to "reduce migratory pressures"7. And "in the area of illegal immigration, partners decide to establish closer cooperation. In this context, aware of their responsibility for readmission, the partners agree to implement bilateral agreements or arrangements to adopt the appropriate provisions and measures for the readmission of their nationals in an irregular situation" $"$.

Thus, the Barcelona Declaration does not deal with the issue of migration, i.e. migration flows and policies, with the exception of clandestine migration. In addition, the Declaration and the Program of Work annexed thereto cover, in the same section and in directly related paragraphs, migration and terrorism, drug trafficking, international crime and corruption!

This way of evacuating the migration issue or of treating it only incidentally ${ }^{9}$ and negatively also appears in the refusal of the European side to include it in the negotiations of the Association Agreements with the Mediterranean countries.

The Euro-Mediterranean Association Agreements, which proceed from the Barcelona Conference, have the same approach as the Barcelona Declaration on migration. Migration is part of the social and cultural component. Regular dialogue is foreseen, with the priority to be given to "reducing migratory pressure" and "reintegration of returnees due to the illegality of their situation"10. Concretely, the results of the social dialogue have led, in the case of Morocco,

5 Cf. Garson J-P. and Barros L. (1998).

6 Migration is not considered an integral part of international trade, unlike goods, services, capital and technology and is therefore not the subject of international agreements that organize it

7 Declaration of Barcelona.

8 Ibid.

9 Garson J-P. and Barros L. (1998).

10 Morocco-EU Association Agreement. Cf. Hamdouch B. (2002). 
to the repatriation of Moroccans in an irregular situation in European countries and to tighter controls on illegal migration from Morocco.

Thus the various Euro-Mediterranean Agreements do not deal with migration or deal with it only incidentally and negatively, and only from the point of view and from the short-term interests of the European Union, by associating it with security issues. Migration policies remain national, subject to bilateral conventions.

\section{The Limits of Migration Policies}

The current migratory crisis is the result of a number of factors: the failure to manage a natural, long, ancient human phenomenon that is constantly being renewed in the face of political, social, economic and climatic hazards. It has been exacerbated recently in the Mediterranean region by wars and political and cultural crises. The migratory crisis is a revelation, a statement of failure of isolated migratory policies.

National measures, carried out in haste, such as the closing of borders and the erection of walls, have resolved nothing. There remain the humanitarian actions carried out by Italy (Operation Mare Nostrum in 2015 and the massive bailouts that continue to be carried out in the Mediterranean by the Italian Coast Guard and some other NGOs) and the massive reception of refugees by Turkey, Lebanon, Jordan and Greece.

European actions have been partial, carried out in haste, and for the most part not followed by effect or not adapted, and hence have not resolved the issue either. European policies for outsourcing and border control are examples such as the agreement between the EU and Turkey of March 2016 to keep Europe-bound refugees and migrants in Turkey or the prospect of agreements with other countries of the Southern Mediterranean (notably Libya) to retain refugees and migrants in camps outside Europe.

There are no regional, Mediterranean, concerted policies involving all partners, all stakeholders. The year 2015, with the arrival of more than one million migrants and refugees in Europe, and the ensuing migratory crisis, show the limits of the partial, national and short-term policies adopted.

\section{Migration Perspectives in the Euro-Mediterranean Partnership}

With the continuation of current trends and policies, the EMP will at best stagnate and the migratory crisis will continue. Everyone will lose, Europe and the countries of the Southern Mediterranean. Hence the need for a new vision of the Europe-South Mediterranean partnership: a true win-win partnership in the current and future global configuration. 


\section{The Facts: the Failure of the EMP and the Handling of the Migration Issue}

The EMP is down and trans-Mediterranean migration is in crisis. EU trade with the southern Mediterranean is stagnant if not receding. Priority has always been given to the enlargement of the EU. This was at the expense of relations with the South. After the great enlargement in the East of 2004 with the admission of ten countries of Central and Eastern Europe, the idea of a rebalancing appeared. The European countries of the Mediterranean have thought of the creation of a Mediterranean Union which would bring the countries of the southern shore closer to the EU. But the project has shrunk to the point of becoming the Union for the Mediterranean. This is mainly focused on sectoral actions. It is an even less ambitious emanation of the Barcelona Conference which has shown its limits.

As far as migration is concerned, it is now clear that bilateral partnerships (between two countries or between the EU and eacha South-Mediterranean or African country alone) are not a good approach to tackle the issue as a whole ${ }^{11}$. The sub-regional or regional attempts to date either:

-Dialogue $5+5^{12}$ concerns only the Western Mediterranean and do not address the issue of migration.

- The Euro-African Conferences on Migration and Development, the first of which took place in Rabat in July 2006, have produced nothing concrete about managing migratory flows and their implications for development.

\section{So What to Do? Some Ideas for Reflection}

First of all, we need to change our approach and paradigm, considering mobility a natural and historical human right, at least as much as the international trade in goods, services or capital flows. Why have we excluded human movements from international agreements on trade liberalization and organization ${ }^{13}$ ? Migration should therefore be integrated into the EMP.

We should then come out of unequal partnerships, old hegemonic schemes to move towards concerted regional migration policies, within the framework of a true "balanced partnership", a global partnership for the interest and development of all the partners. This requires a new vision and approach.

A proposition in this direction could be the creation of a Euro-African Alliance for Migration and Development. Morocco has already proposed the creation of an African Alliance for Migration and Development. It could be a first step, which would allow the African countries concerned to form an "alliance", to speak with one voice with the EU.

11 Cf. Hamdouch B. (2016).

12 Mauritania,Morocco, Algeria,Tunisia, Libya;Portugal,Spain,France,Italy and Malta.

13 This is what the GATT did and after it the WTO. 


\section{What Future for Trans-Mediterranean Migrations?}

This will depend on the end of the political, economic and cultural crises in the region and the establishment of a regulatory and operational framework for managing migration. Having failed to implement national, regional, and in particular European and Euro-Mediterranean migration for development policies in due course, the countries of Europe and South and East Mediterranean are currently in the midst of a migration crisis.

The resurgence of migration flows was observed after the previous crises, the penultimate one being that of the early 1970s. The demographic imbalances being what they are on both sides of the Mediterranean, one can expect a revival of trans-Mediterranean migratory flows as growth picks up and Europe "digests" the numbers of newly arrived migrants and refugees. But flows will evolve in their intensity, their geographical distribution and their characteristics according to the needs of some and the availabilities of others: types of migrations, temporary, circular or long, levels of qualifications, specialties...

There remains the issue of the approach, the regulatory framework and migration policies. Will we learn from the recent past, from the current migratory crisis to adopt a new vision, in the long term, a global partnership that includes migration, a global partnership that is "balanced", sustainable and in the best interests of all partners, a win-win partnership?

\section{Conclusion: Euro-Mediterranean Migration and Partnership Can Have a Future}

The EMP is going badly. It is "mal parti” (badly gone) to quote the title of René Dumont's work on development policies in African countries in the post independence era ${ }^{14}$. Migration and the EMP are currently at an impasse. To do nothing is to let the crisis set in. Is the EMP, including migration, doomed to failure? Yes, if we continue along the same path. No, if we change course, approach, and paradigm. Then migration and the EMP, migration in the EMP can have a future in a Mediterranean Area or a Mediterranean Union to be built, which would be the counterpart of the other major global poles, North America, China, India ...in a global economy and a global world. 


\section{References}

Garson J-P. et Barros L. (1998). Migration et intégration régionale : l’Union européenne face aux pays tiers du bassin méditerranéen, in OCDE.

Hamdouch B. (Dir.) (2016). L’Avenir des migrations transméditerranéennes - Au-delà des crises. Rabat : AMI.

Hamdouch B. (avril 2002). La transformation de la migration internationale marocaine et le partenariat euro-méditerranéen, INSEA, Cahiers de recherches démographiques, No 2.

Hamdouch B. (2001). La Migration dans le partenariat euro-maghrébin, in le Partenariat euro-méditerranéen (sous la direction de B. Khader), CETRI, Louvain-la-Neuve et l'Harmattan, Paris.

Hamdouch B. (2000). Morocco - EU Partnership, in Economic Trends in the MENA Region,. Cairo: Economic Research Forum (ERF).

OCDE (1998), Migrations, libre-échange et intégration régionale dans le basin méditerranéen, Paris.

OCDE, Tendances des migrations internationales, rapports annuels. 